\section{Nothing but the facts?}

\section{Jeremy A. Sabloff}

What is Archaeology? An Essay on the Nature of Archaeological Research. By Paul Courbin. Translated by Paul Bahn. University of Chicago Press: 1988. Pp.197. \$24.95, £19.95.

ARCHAEOLOGISTS who enjoy watching William F. Buckley skewer a liberal guest on the American television programme Firing Line, or relished Malcolm Muggeridge making mincemeat of a pseudointellectual, are certain to have a great time reading Paul Courbin's book. What is Archaeology?, which was originally published in 1982 in French, is a short, harsh attack on the 'new archaeology' of Lewis R. Binford, David Clarke and many others who have tried to improve archaeological knowledge over the past three decades. I savour a good polemic as much as anyone, yet when I finished the book I was left with the same feeling that most of us have when we have eaten a plate of junk food. It's been fun, but one can have too much of it.

For many scholars, the nature of archaeological research has changed dramatically, albeit sometimes painfully,

\section{The New World of archaeology}

IN HIS review of The Pastmasters (facing page) Warwick Bray voices the mild complaint that the Americas are underrepresented in the collection. Partially compensating for that deficiency is a similar kind of book, Portraits in American Archaeology: Remembrances of Some Distinguished Americanists, to be published on 28 April by University of New Mexico Press (price hbk \$35, pbk \$19.95).

Unlike the essays in The Pastmasters, all of the portraits are a product of a single hand, that of Gordon R. Willey. But both books reflect earlier times when archaeology was very different - less 'scientific' but, on Willey's evidence, rather more pleasurable to work in, because only a small fraternity was involved. As Willey writes in his preface, of when he was starting out on his career in 1937: "the annual meeting of the Society for American Archaeology . . . was held in a single room and with single sessions. Attendance was probably on the order of $\mathbf{3 0}$ or $\mathbf{4 0}$ of us, young and old.... We were terribly dependent upon each other".

There are 16 portraits altogether, an avowedly personal selection of people Willey knew and liked. This is no reference work; but it is well-written and enlightening, and imbued with the author's affection for his subject.

T.L. since the early 1960 s. Archaeologists now try to understand long-term cultural changes and have developed innovative techniques and methods to reach this goal. Both the planning of research and the interpretation of research results have become much more rigorous. Other tenets of the new archaeology, such as the necessity of a deductive-nomological approach to establish archaeological laws, appear to have failed to take hold.

Courbin, a professor of archaeology at the Ecole des Hautes Etudes en Sciences Sociales in Paris, denies that any significant changes have taken place. He zeroes in on the excesses of the new archaeology with scathing sarcasm that - in Paul Bahn's effective translation - dissects the jargon-laden claims of many writers with great dexterity. But Courbin is so blinded by outrage that he loses sight of several of the new archaeology's genuine accomplishments.

Although Courbin has been assiduous in reviewing the theoretical or programmatic literature, he does not pay equal attention to the literature documenting fieldwork. Why, just to give a few examples from the New World, is there no mention of Howard D. Winters' pathbreaking The Riverton Culture (Illinois State Museum, 1969) or of the reanalyses undertaken by Stuart Struever and others of the Hopewell culture? Why is a diagram from David Hurst Thomas's Great Basin research reproduced but the innovative fieldwork ignored? Why, unless Courbin considers it traditional archaeology, is there no citation of Kent V. Flannery's important The Mesoamerican Village (Academic Press, 1976)? Why, in the text itself or in his new introduction to this English edition, does he not recognize the growth and development of Binford's thinking or the changes of emphasis in the work of Patty Jo Watson and her colleagues (compare Explanation in Archeology, published by Columbia University Press in 1971, with Archeological Explanation, issued by the same publisher in 1984)?

Courbin would have the reader believe that the new archaeology has failed and that traditional archaeology triumphantly continues on. This contention is not correct. Although many of the specific proposals of the 1960 s and early 1970s have not been followed, the practice of archaeology in the New World and elsewhere has been profoundly affected by fresh ideas.

In my view, the most notable changes have been methodological in nature, not theoretical. Courbin is correct when he argues that there has been relatively little progress in theoretical understandings of long-term change. But he does not acknowledge that much effort has gone into developing methodologies that have the potential to lead to new understandings. Certainly, there is no evidence

\section{Outstanding publications} from Kluwer...

\section{Random Fluctuations and Pattern Growth:}

\section{Experiments and Models}

Proceedings of the NATO Advanced Study Institute held at Cargèse, Corsica, France, July 18-31, 1988

edited by $\mathbf{H}$. Eugene Stanley and Nicole Ostrowsky

NATO ADVANCED SCIENCE INSTITUTES SERIES E: Applied Sciences 157

Contains articles on topics ranging from membranes and liquid crystals to turbulence.

1988, $368 \mathrm{pp}$

Hardbound Dfl. 180.00/£59.00/US\$89.00 ISBN 0-7923-0072-6

Paperback Dfi. 65.00/£19.95/US\$29.00 ISBN 0-7923-0073-4

\section{Disorder and Mixing}

Convection, Diffusion and Reaction in Random Materiais and Processes

Proceedings of the NATO Advanced Study Institute on Disorder and Mixing, Cargèse, Corsica, France, June 15-27, 1987

edited by Etienne Guyon, Jean-Pierre Nadal and Yves Pomeau

NATO ADVANCED SCIENCE INSTITUTES SERIES E: Applied Sciences 152

This book is the first attempt to present in a unified fashion the various approaches of statistical physics and fluid mechanics, with illustrations chosen from typical problems in engineering.

$1988,360 \mathrm{pp}$

Hardbound Dfl. $160.00 / £ 47.00 /$ US $\$ 79.00$

ISBN 90-247-3788-5

Paperback Dfl. 70.00/£20.50/US\$29.00

ISBN 90-247-3789-3

\section{Structures of Ophiolites and Dynamics of Oceanic Lithosphere}

edited by $\mathbf{A}$. Nicolas

PETROLOGY AND STRUCTURAL GEOLOGY

This unique, well-illustrated work will serve as an invaluable reference to marine geologists and geophysicists, petrologists and, more generally. scientists interested in geodynamics.

$1989,350 \mathrm{pp}$. ISBN 0-7923-0255-9 Hardbound Dfl. 195.00/£62.00/US $\$ 99.00$

\section{Reference Frames}

edited by J. Kovalevsky, I. I. Mueller and B. Kolaczek

ASTROPHYSICS AND SPACE SCIENCE LIBRARY 154

This work will be a reference for all scientists working in astronomy, geodesy and geophysics.

$1989,475 \mathrm{pp}$. ISBN 0-7923-0182-X Hardbound Dfl. 195.00/£59.00/US\$99.00

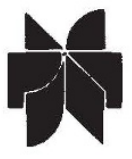

\section{Kluwer academic publishers}

PO. Box 322, 3300 AH Dordrecht, The Netherlands

P. Box 358, Accord Station, Hingham, MA 02018-0358, U.S.A. Reader Service No.14 


\section{NEW BOOKS}

\section{Plant Taxonomy and Biosystematics}

\section{Second Edition}

\section{CLIVE A STACE}

- The first edition of this book received excellent reviews and has become the standard work on plant taxonomy for undergraduates

April $1989 £ 14.95$ net paperback 272 pages ISBN 0713129557 Iine and half-tone illustrations

\section{Protozoa and Other Protists}

MICHAEL A SLEIGH

- Provides a complete introduction to contemporary knowlege concerning protozoan biology which is a fundamental component in the elucidation of marine and freshwater processes

June 1989366 pages approx $\$ 30$ net approx hardback ISBN 0713129794

$£ 20$ net approx paperback

ISBN 0713129433

Line and half-tone illustrations

\section{Genes and Gene Regulation \\ NORMAN MACLEAN \\ New Studies in Biology \\ May $1989 £ 6.95$ net paperback 144 pages ISBN 0713129514}

\section{Phytoplankton \\ Second Edition}

A D BONEY

New Studies in Biology

May $1989 £ 6.95$ net paperback

128 pages ISBN 0713129786

Line and half-tone illustrations

Reader Service No.23

Edward Arnold A division of

Hodder \& Stoughton 41 Bedford Square London WC $1 B$ 3DQ

Telephone: : 01-637 7161 whatsoever that the methodologies of traditional archaeologists were leading to any advances along these lines. Even the old boasian belief, that 'when the facts are in, new theoretical understandings will emerge', eventually gave way in American anthropological thinking to the realization that that great day would never arrive.

Of particular relevance to methodology was the argument by Binford and others that culture is variable, not homogeneous. From this premise, it follows that archaeologists need to cope with variability in as rigorous and systematic a fashion as possible. Such thinking implied that overall research strategies and the means by which variability could be recognized in the archaeological record had to change. Problems of sampling became paramount in fieldwork and highlighted the need to give explicit attention to the ways in which meaning was routinely assigned to various patterns in that record. This argument cannot be dismissed by those such as Courbin who say that archaeologists are interested first and foremost in gathering 'facts'. What kinds of facts are they collecting and how useful will they be if sampling problems are ignored? New perspectives on the Maya, for instance, have shown how traditional views focused only on élite aspects of the civilization and missed much of the rest of activity in that society.

So Courbin's contention that traditional archaeologists can continue with business as usual, at least in the Americas, is disingenuous at best. To my mind, what he is calling for is for the clocks to be turned back to the pre-1960s. But as David Clarke so insightfully argued in his article "Loss of Innocence" (Antiquity 47, 6-18; 1973) - an important paper not discussed by Courbin - once archaeologists' eyes have been opened to the critical role their biases and perspectives play in uncovering and interpreting data, they cannot close them again. Thus I would argue that archaeology should not be limited to the 'establishment of facts'. Courbin's separation of the archaeologist as archaeologist recovering and analysing facts, and the archaeologist as anthropologist or historian interpreting them, is hopelessly naive.

Courbin acknowledges that there are no archaeological facts waiting to be discovered. He understands that archaeologists bring "frames of reference" (to use his term) to their examination of the archaeological record and that some degree of interpretation is necessary in the establishment of facts. Archaeologists, for example, usually do not discover perishable houses, but instead uncover circles of stone that they interpret by analogy as dwellings. It is in this critical area that Courbin is at his weakest. He seems confused, for instance, when he says (p.122):

Finally. I can reassure those who might think it humbling to devote oneself to the establish- ment of archaeological facts. This is not as unworthy of their immense talents as it might seem. If truth be told, it is not easy; it is an enterprise that is at least as difficult as, and perhaps more so than, the invention and demonstration of a law (or would-be law) or the building of a theory, be it "middle-range" or general.

Courbin does not seem to realize that middle-range theory helps the archaeologist bridge the gap between the static archaeological record and all kinds of interpretation, which often include the traditional archaeologist's 'facts'. Although Courbin recognizes that facts involve interpretation, and that establishing them is often a difficult procedure, he mistakenly insists on separating the activity of establishing facts as purely archaeological and the further interpretation of them as something else that archaeologists do that is anthropological or historical but not archaeological. In the process of assigning meaning to the data on the ground - in their reporting of facts - archaeologists function as anthropologists or historians, whether such actions are explicit or implicit.

In addition, Courbin's dismissal of materialism as deterministic is too simplistic and not well argued. He falls into the same trap that he derides the new archaeologists for falling into; namely, labelling an argument and assuming that the label itself is sufficient refutation. As Leslie White, some years ago, and Marvin Harris, among others, have demonstrated, being a materialist (or being ecologically orientated) does not mean that one does not believe in personal liberty.

What is Archaeology? is definitely worth reading. Archaeologists and knowledgeable scholars from neighbouring disciplines will find that it will help sharpen their thinking about modern directions in archaeological thought. Like most polemical tracts, it will either have you cheering or have your blood boiling Courbin takes no prisoners. But students or others unfamiliar with the controversy over the new archaeology should read it in conjunction with other books, for example Lewis R. Binford's In Pursuit of the Past (Thames and Hudson, 1983), Ian Hodder's Reading the Past (Cambridge University Press, 1986) or the second edition of the late Glyn Daniel's Idea of Prehistory (Edinburgh University Press, 1988), paying particular attention to Colin Renfrew's two new, informative chapters. I believe that such comparative reading will convince the bystander that Courbin's critique misses the mark. Collecting 'facts' is not a sufficient rationale for archaeology - the discipline is and can be much more.

Jeremy A. Sabloff is University Professor of Anthropology and the History and Philosophy of Science at the University of Pittsburgh Pennsylvania 15260, USA 